\title{
Innovative Mindset in School Education: A global issue or trend in Pakistan
}

\section{Syeda Saira Hamid ${ }^{1}$}

${ }^{1}$ National University of Modern Languages, Islamabad

\section{A B S T R A C T}

Education and training are emerging now key drivers of competitiveness for any country on the globe. To cope with the globalization a country has to elevate her education system. In Pakistan, HEC upgraded the Teacher Education (TE) by replacing the one-year B.Ed. with the 4 years B.Ed. (Honors). The upgraded TE and the global challenges are well connected with the real implementation of vision 2030 agenda in the School Education (SE). And very crucial to address the advancements in TE for the production of teachers with the innovative mindset to grip the global reach in the future. The Punjab government is planning to stop the upgraded 4-year program offered since 2009 in the 33 Government Elementary Colleges for Teachers Training (GCETs) instead of making them self-sustain. The study with main objectives: i) to collect, need assessment data for the global advancements adaptation from the GCETs. ii) To analyze critically educational documents along with the budget allocation for globalization. iii) To propose a conceived factual framework for transforming teacher education in Punjab was conducted by utilizing mixed research methods, visualized the advanced professional training needs and essential global interventions. Then it strived to propose a transformation mechanism for the elevation of TE. The data analyzed quantitatively and qualitatively through percentages, triangulation and content analysis. The study resolved the globalization issue, by bridging the gaps through a transformation framework outlines for modification in TE. The conceived factual framework is a dynamic revolutionary route to improving the quality of school education via contemporary TE. The suggested framework if implemented in future after validation it would save the scarce resources and provide maximum outputs through quality education.

Keywords: Global advancements, Dynamic transformation framework, Innovative mindset

\section{INTRODUCTION}

We are living in the revolutionary era of information technology with swift advancements in every walk of life. The concept of the global village is now transformed into a global table. The blast of electronic media along mobile gadgets has also altered the way of 
social living, modifying the pattern of acquiring knowledge and learning. Schools, as well, should respond to such advanced societal needs. And consequently, schools must re-think and re-emphasize the development and implementation of a new curriculum and pedagogy. As mentioned by Shah (2004), "that schools should develop and reform their curricula in a way that produces the necessary human capital capable of holding up to the government's growing economy and growing population, along with identifying viable solutions for such crucial and vibrant needs". There is a dire need to adapt wisely the new global trends in our educational system rather making them issues.

The key findings of the 2015 Global Monitoring Report (GMR) Education for All (EFA) 2000-2015: Achievements and Challenges' produced by UNESCO, which has tracked progress on these goals for the past 15 years. Pakistan has not reached any of the EFA goals set in 2000 with measurable targets. To improve the quality of education, 4 million more teachers are still needed. The trained teachers remain in short supply in onethird of countries; in several sub-Saharan African countries, less than 50 percent are trained. However, education quality has received increased attention since 2000 and now with the major focus on the vision 2030 agenda. (GMR -Report, 2015).

According to the vision 2030, under the caption, "The Teacher for the $21 \mathrm{st}$ Century" Teachers are the long pole in the tent of education in school to higher education. Having good teachers can dramatically affect the quality education. The teacher numbers are inadequate in schools and colleges, and their background lacks both solidity and diversity; they are also paid very little. From a policy viewpoint, the primary objective would be to attract better teachers and secondly to improve their overall quality. Better salaries and facilities will produce the desired result. Teachers must be enabled to acquire a decent measure of 'self-esteem'. This has happened in universities and it must now be implemented with even greater emphasis on the school level. (National Economic Council, Vision 2030 paper, 2007).

\section{Rationale:}

In the present scenario of Pakistan, there is more than thirty-six percent (36\%) children, out of school at primary level. Numerous funding agencies and foreign aids 
have worked on the enhancement of a quality education through increased enrollment, high literacy rate, improving infrastructure, and significant teacher training, to provide a suitable learning environment. But only short term benefits and improvements were achieved through such makeups. That is true and prevailing situations. (UNESCO, 2015) The truly required efforts are not made because the root- causes are ignored. Ultimately the problems reappear with high intensity, like a disease that required surgery, but was treated with a painkiller instead. In an education system if the solutions are temporary, then such shallow solutions will eventually evolve into unresolved issues. And sometimes the institution, itself, is connected with the root causes of the problem as Chubb and Moe argued, that institution being a part of the problem cannot solve the problem alone. (Chubb, Moe, 1990)

The same situation exists in the educational system of Pakistan as well, where the schools and colleges in the public sector are not self-sufficient and self- sustained to deal with all sorts of issues, chiefly advanced CPD and their finances. More researchers are required to pinpoint the hidden causes and to give long-lasting way-outs to resolve the issues for the quality enhancement mechanism. In the province, Punjab, there is urgency for good governance and effective management that includes innovative reforms the education system through teacher education institutions (TTIs).

Whereas the Punjab Government privatized more than four thousand schools and planning to stop the 4-year B.Ed. (Honors) in the 33 GCETS, instead of making them self-sufficient and self-sustain to supply an excellent lot of teachers. The study attempted to conceive a dynamic transformation process to resolve the existing issue in GECTS of Punjab in the form of factual framework. That might be a very leading and supportive route in the planning process of school education department and if implemented in future after validation.

\section{LITERATURE REVIEW}

The first and most important thing is that no education system can be better than the quality of its teachers. The most successful countries, from the Far East to Far West are those, where teaching has the highest status as a profession. All the evidence from 
different education systems around the world shows that the most important factor in determining how well children do is the quality of the teachers and the teaching. The core of the education system, the Teacher Education, (TE) is the most neglected and ignored areas in Pakistan. It does not even receive the sympathetic attention for the sake of country's future growth and sustainable development. That explains why our TTIs are not well equipped to prepare quality prospective-teachers, encounter the global demands. (education.vermont.gov, n.d.)

The best education systems in the world draw their teachers from among the top graduates and train them rigorously and effectively, focusing on classroom practice. They then make sure that teachers receive effective professional development throughout their career, high social status, opportunities and other benefits. Considering the teacher education as the mother of education systems, the policy makers, planners and the politicians in our country should give the highest priority to teacher education for the sake of a robust and sustained education system, but the situation is reversed in Pakistan. Many types of research recognized that there are too many teachers who lack knowledge of the content, pedagogical skills and need CPD to address the demands of their advanced learners from the modern age of technology. (undp.org, n.d.).

According to the ministry of education, In Pakistan, the total teacher training institutions(TTIs) are 147, with 3232 teachers- educators in the public sector and only 23, with 266 teachers- educators in the private sector. (AEPM, 2011-2012). In both sectors, the limited teacher training institutes face the challenges of preparing the perspectiveteachers for new generations and utilizing the advanced learning theories and acquired modern pedagogy. Both need curricula revise and wise planning with budgetary proficiency for adapting the global advancements. The required advancements can be tailored locally according to the needs for preparing quality prospective teachers for the future generation. (TE. net.Pk, n.d, n.d.)

\section{Teacher Education: Current Situation in Punjab:}

There are 40 teacher training institutes (TTIs) in different universities and 33 Government Colleges for Elementary Teachers Training (GCETs) for pre-service and in- 
service teacher education in Punjab under the directorate of staff development (DSD).The present status of TE in the public sector of Punjab is not up to the mark, to encounter the global advancements and survive in the vibrantly changed social environment. (Shah, 2010)

According to the SAP 1995 report, in two separate types of research, "the quality and quantity of content taught in pre- service and in-service teacher education programs is poor and low in Pakistan." Most of the teacher education programs have an old- dated curriculum with poor levels of instruction, for example, PTC or CT (Khan 2004).

The NACTE established National standards for accreditation of pre- service teacher education programs offered in the country by defining the essential components and aligned the standard framework. The consultants were hired and the consultancy was done. Finally, the consensus on the provincial and national level was developed in June 2009 and in July 2009 the standards were approved by the NACTE. It was a forwarding phase of quality education. The ministry of education policy and planning wing in collaboration with UNESCO implemented the STEP (Strengthening Teacher Education in Pakistan). Under the Pre-STEP project, the national professional standards for teachers (NPST) were developed. (NACTE, 2009)

\section{New global Trends: Accreditation, Teacher licensing and NPST:}

The process of TE program accreditation, teachers licensing and certification in advanced countries like U.K, Australia, America and Canada is done by their government. Considering the teacher's competency for quality education and realizing it as a new global demand. National professional standards for teachers (NPST) and national accreditation council for teacher education (NACTE) were developed by Higher Education Commission of Pakistan (HEC) in 2009; the process of the teacher licensing and function of NACTE is still under consideration at the upper level. (HEC, 2009).

\section{Good Governance: Another Global Demand in Teacher education:}

In Punjab, there is an education, emergency because the literacy rate is about $40 \%$ $50 \%$ There is urgency for good governance, effective management and a control mechanism that includes innovative reforming the education system through (TTIs), 
making them eligible to compete globally. And the expenditure on education should clearly be more than 2.5\%. (Planning commission 2012-2013).

The Education policy 2009, NACTE and NPST along new programs, B.Ed. (Honor) launched by USAID under the STEP project The new 4 programs are supposed to replace all the one-year teacher education programs in the year 2018. (NotificationSED, Punjab 2013).USAID-Pre STEP project has given maximum support in developing new curriculum and trained the faculties in twenty GCETs offering the new 4-year program. The STEP project was over in June 2013.

\section{Statement of the Problem:}

The globally competitive quality education is the agenda of vision 2030 for the economic growth and sustainable development of our country. There is a dire need for a dynamic transformation mechanism to adapt the global advancements through quality teachers. The study addressed the globalization and its required reforms through a transformation mechanism in school education.

\section{Objectives of the Study:}

The objectives of the study were:

- To collect, need assessment data for the global advancements adaptation from the GCETs.

- To analyze critically educational documents along with the budget allocation for globalization.

- To propose a conceived factual framework for transforming teacher education in Punjab.

\section{The Research Questions:}

Q1: What are the demands of principals, teacher-educators, and prospective teachers for the new global trends?

Q2: How the education policy, NPST, new curriculum and budget allocations are aligned with the global demands?

Q3: How, where and why to bridge gaps locally with the advanced global interventions in teacher and school education?

\section{The significance of the Study:}


The study has a grand weight for the school education department (SED).The suggested dynamic transformation process is a research based and the proposed academies will be an excellent source for achieving the vision 2030 targets. The transforming framework if implemented can be very supportive in boosting the economic growth through quality education.

\section{RESEARCH METHODOLOGY}

The study employed the mixed methods of research by focusing the quantitative and qualitative aspects. The population was comprised of 73 Teacher Education Institutes in the public sector of Punjab. Among which, the 40 (TTIs) are working in universities as autonomous bodies and the 33 Government Colleges for Elementary Teachers Training (GCETs) are working under the directorate of staff development (DSD) and school education department (SED).

\section{Sampling:}

The 33 GCETS, (45\%) of the population was selected as purposive random sampling. The representatives of both genders i.e. male and female were selected randomly. All the principals (100\%) were selected, and among 402 teachers-educators (SS/SSS) 330 (82\%) were randomly selected. Among 506 perspective -teachers only 200 $(39.5 \%)$ were selected randomly.

The reasons behind the purposive samplings were to include the people of central interest with particular characteristics, i.e., the TE in the public sector of Punjab. As viewed that, "key informants can be used to find purposive sample". (Barany 2006). "Both random and purposive sampling can be combined to produce a powerful way of sampling”. (Albertan, Nair, 2004).

\section{Delimitation of the study}

The study was delimited to the teacher education in Punjab and the vast concept of globalization was also restricted to globalization in education due to time and financial constraints.

\section{Instruments of the Study:}


Three types of questionnaires for principals, teacher educators, and prospective teachers were utilized. Focusing the qualitative aspects the other instruments were: i) Focused group discussions ii) Semi- structured interviews with Principals .iii) Classrooms observations and Checklists.

\section{Validation of the instruments:}

The pilot testing was done for the reliability of the instrument and the validation was done with the help of experts. The 3 types of questionnaires were constructed; each item was revised accordingly. Furthermore, the interviews, focused group' discussion, classroom observations and documents analysis questions were also refined with experts.

\section{Data Collection and Analysis:}

The questionnaires were distributed with the covering letter from DSD via e- mail. The frequencies and percentages were calculated for each statement. Then triangulation of data was done with three variables: the Principals, the teacher- educators and the prospective teachers. The document's critical analysis was done along cost-benefit analysis ratio $(\mathrm{CBR})$ in budget allocation by the focal questions:

- Is the analyzed document updated for the demands of globalization advancements?

- Is there any identified implementing authority existing or not?

- What are the practical aspects of the documents regarding local and global considerations?

\section{Data Triangulation Interpretations:}

Table.1: The ranks A-E with the scale value 5-1

\section{Various options in the questionnaires}

Almost totally, Expert, Strongly Agreed, Excellent

Quite almost, Very Good, Agreed, very Good

Moderately. Competent, Not Know, Good

Slightly, Modest, Disagreed, Fair

Not at all, Needs improvement, St. Disagreed, Poor
Scale Number

5

4

3

2

1
Assigned Ranks

D
A B

C

D

E 
In three questionnaires almost all the respondents were at rank $\mathrm{A}$ and $\mathrm{B}$ in adapting global advancements through training. Ranks D-E are obtained for all the respondents in English communication, use of IT, computer skills, School based task (SBT), Student Independent Learning Time (SILT), global citizenship skills-critical, analytical and creative thinking and etc. It was concluded a serious change for quality education is required to bridging the traced gaps.

The data triangulation was very effective to draw a clear cut picture about the need-analysis for the globalization of education. The qualitative aspects were also analyzed and the findings were indirectly crossed checked and then inculcated in the triangulation and content analysis. Content analysis of open-ended questions finally concluded in content analysis matrix (CAM). According to Holsti (1969) "Content analysis is any technique for making inferences by objectively and systematically identifying specified characteristics of messages." (Holsti, 1969)

The content analysis conceived as that the main aim of TE is to promote the innovative mindset, intellectual growth and moral dispositions in the future teachers through innovative pedagogy. There is a need for adaptation-trainings to nurture the intellectual growth and wisdom through reflections, discussions and active engagement in the critique of existing knowledge and practices that could implement educational policies and practices at the classroom level. 
Table.2: Content analysis matrix

\begin{tabular}{|c|c|c|c|}
\hline $\begin{array}{l}\text { Respondents } \\
\text { In GCETS }\end{array}$ & $\begin{array}{l}\text { How Important } \\
\text { High - Medium - } \\
\text { Low }\end{array}$ & $\begin{array}{l}\text { What They Demand as } \\
\text { a global trend }\end{array}$ & $\begin{array}{l}\text { How it should be done as } \\
\text { local interventions }\end{array}$ \\
\hline Principals & High & 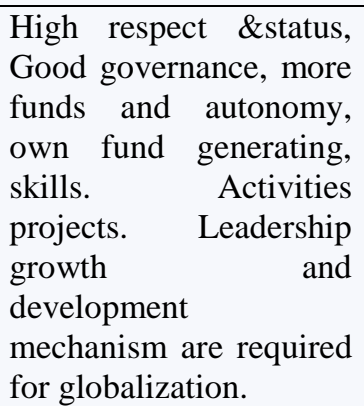 & $\begin{array}{l}\text { The ownership, respect, } \\
\text { skills and strategies achieved } \\
\text { by revising the setup as } \\
\text { autonomous. Diagnostic } \\
\text { foreign tailored training with } \\
\text { the continuous feedback } \\
\text { \&follow up. }\end{array}$ \\
\hline $\begin{array}{l}\text { Teachers } \\
\text { Educators } \\
\text { S.S/S.S.S }\end{array}$ & High & $\begin{array}{l}\text { Need to be based } \\
\text { tailored training instead } \\
\text { are required for the } \\
\text { intellectual growth, } \\
\text { command on } \\
\text { collaborative pedagogy, } \\
\text { HEC Revised } \\
\text { curriculum \&recognized } \\
\text { TE programs, High } \\
\text { social status, incentives. } \\
\text { Diagnosed training in } \\
\text { science, social studies, } \\
\text { and mathematics on a } \\
\text { cyclic basis designed on } \\
\text { misconceptions } \\
\text { interactive pedagogy. }\end{array}$ & $\begin{array}{l}\text { Notification of High status, } \\
\text { pay equal to ministers, } \\
\text { Special field researchers by } \\
\text { prospective teachers } \\
\text { supervised by teacher } \\
\text { educators as in (SBT) and } \\
\text { (SILT) to know the ground } \\
\text { realities in school education. } \\
\text { School improvement plans. } \\
\text { Strictly follow the NPST for } \\
\text { expertise on the subject, } \\
\text { quality education and } \\
\text { teacher licensing. A } \\
\text { mechanism for global } \\
\text { advancement adaptation is a } \\
\text { must. }\end{array}$ \\
\hline $\begin{array}{l}\text { Prospective } \\
\text { Teachers }\end{array}$ & High & $\begin{array}{l}\text { Trained teachers- } \\
\text { educators, } \\
\text { approved interactive } \\
\text { curriculum by HEC, } \\
\text { well-equipped science, } \\
\text { computer labs with the } \\
\text { internet, } \\
\text { infrastructure. }\end{array}$ & $\begin{array}{l}\text { Conducive and secure } \\
\text { learning environment with } \\
\text { all required facilities and } \\
\text { infrastructure, Adding new } \\
\text { subjects and Multigrade } \\
\text { teaching in the curriculum. }\end{array}$ \\
\hline
\end{tabular}

\section{Findings and Conclusion:}

The findings on three types of responses through quantitative and qualitative aspects were:

The Majority of the Principals (99\%) said the principals are the vital policy implementers so they need autonomy, latest training; sufficient budget, more staff in IT and sciences. 
The better infrastructures along basic resources are urgently needed. The institutions should be autonomous to deal with complex role and responsibilities in the combined GCETS \&DTSC units. It can be concluded that there is an overall demand for a new set up in teacher education ultimately linked with quality drive in school education department.

All most all (89\%) teachers- educators have views that they should be involved in developing and revamping the new curriculum. The diagnostic training should focus the policy actions, NPST, accreditation and the venue and weather to make the training more effective. The follow-up mechanism should a major component.

All the prospective teachers (100\%) pointed out that there is a need for democratic and open-minded administrators along expert teacher- educator's team. The activities like Practicum SBT and SILT well managed and facilitated. Advanced management services with latest equipment and infrastructure along the provision of all the basic facilities should be provided immediately. It is concluded that the new global trends like NPST and NACTE now must be implemented to fill the gaps and remove the bottlenecks in the preparatory process of quality teachers.

Considering the findings, data triangulation and content analysis the researcher developed a research-based factual framework with the rationale for the implementation is outlined. However, the validation was not done as it was not a part of the objective.

The rationale for the Suggested Dynamic Transformation Framework for Future:

The framework is research based and is the reflection of the major stakeholders concerned with the quality teachers' production and overall quality education with following focal points.

\section{A Genius Amalgamation of DSD, GCETS, and DTSC:}

The research proceeded in a systematic way, starting from collecting need assessment data for global advancements, analyzing the policy demands, new curriculum implantation requirement, and budget allocation along cost per student and teacherstudent ratio in GCETS. Considering all the ground realities and for the sake of quality education and training at global standards, the merging is indispensable. 


\section{Growth within the Available Collective Resources and Cost-effectiveness:}

\section{DYNAMIC TRANSFORMATION- FACTUAL FRAMEWORK}

Globalization Adaptations On global Agenda Vision 2030

align with

Our Islamic Philosophy \&Ideology, Cultural \& Social Values, Society demand\& Our Leaner's ability, psychology\& other up comings

The focal logic and justification are that, the highest escalation and production within the available collective- resources that can be effectively utilized to serve for the quality school education and training. The proposed academies will provide maximum outputs in term of multidimensional services.

\section{Saving of Limited and Scarce Resources:}

Considering the calculated cost-benefit ratio for the Islamabad and Rawalpindi GCETS campuses that was 300000-700000 per student respectively, for the year 20132014. And the total budget allocation for the DSD, DTSC and the thirty-three GCETS, was 4.5 billion for the same year. Among which, 99 million were allocated to the GCETS the remaining is utilized by the DSD and DTSC. The merged academies can serve better than the DSD and DTSC to save, the more than 2 billion rupees annually. As the quality assurance reports and third party evaluation is not in the favor of DSD and DTSC.

\section{FINAL CONCLUSIONS}

The new global trends like NPST, NACTE and 4 years teacher education programs are now indispensable to implement for preparing quality teachers in the country. There is an overall demand for a new set up accompanying good governance for quality education. There is an intense and urgent need to transform the existing TE system in Punjab instead banning the new entry of 4-years B.Ed (Honors). The modified role will be able to cope with the globalization and global market. And also maximize the economic growth through a versatile true leadership.

It will serve a true spirit of innovation in administration, management, supervision and pedagogy to produce innovative mindset in our upcoming future generation. The 


\section{Transforming the Role by Merging DSD, GCETs, and DTSC}

For the good governance, Quality education, Quality Teacher Production Global advancements adaptation \& Sustainable development economy boost, \&etc into

\section{PFALTE\&R}

Pakistan Future Academies for Leadership, Teacher Education, and Research

Autonomous bodies of International Level, on the pattern of Armed Forces Academies

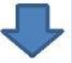

\section{PFALTE\&R}

TE (Pre\&In service) + TLU + CRW (Quality Science Teachers for SE)

R)
With attached Units

\section{DTSC+CCU+FS}

(NPST,P,FBR\&

Activities On Campus and In Field- Monthly, Quarterly Biannual and Annually

Foreign\& In-country Online tailored professional, Leadership, Academic Trainings

Modules development, Master Trainers' pool, Curriculum Revamping, Field feedback \&Researches for Reforms through Training Need Assessment

Academic Heads, Educators/Master Trainer exchange at international/national level

Dissemination \&adaptation of all the knowledge, skills, tactics and reforms from central to grass root level through

Academies by TE, Trica FS by reflective practitioners, cluster center by TE (on Field)

suggested framework outlines for the dynamic transformation process at table- 3

Note: The Regional level total 8 Academies 4 for boys \& 4 girls at Islamabad, Lahore, Multan, and Bahawalpur. The 21 GCETs converted into Academies' Sub- Campuses as Training \& Model Higher Secondary Schools serve as Feeder center to preparing $\left(8^{\text {th }}-12^{\text {th }}\right.$ class $)$ quality stuff for the regional Academies further prepare Future Science teachers to serve the SED.

\section{ACRONYMS}

$\mathrm{CC}$

CPD

Cluster centers

CRW

Continuous professional development

DTSC

Curriculum Development wing

FS

District Training and support center

FBR\& R

Family Schools

NPST

FeedBack \& Reforms

$P$

PFALTE\&R

National Professional Standers for Teachers

TLU

Practicum (Teaching Practice/Putting theory into Practice)

Pakistan Future Academies for Leadership, Teacher Education, and Research

REFERENCES

Teacher Licensing Unit

Andrew, Dobson. (2006). "Thick Cosmopolitanism”, Vol 54, pp. 165- 184.2006.

Andrew, Jones. (2006). "The Dictionary of Globalization”, Cambridge, International, publisher.

Albert, A. \& P.K.R Nair (2004). "Framers' perspectives on the role of shade trees in a coffee production system: an assessment from the Nicoya Peninsula, Costa Rica". Human Ecology 32:443-463

Altrichter, H., Posch, P. \& Somekh, B. (1996). "Teachers investigate their work; an introduction to the methods of action research". London: Routledge 
Bates. R. (2008). "Teacher education in a global context: Towards a defensible theory of teacher education", Journal of Education for Teaching, 34 (4): 277-293.

Barany, M.E.(2006). Non -timber forest products in the livelihood and coping strategies of household and communities afflicted by HIVIAIS Master thesis.Virginia Polytechnic Institute and state university, Blacksburg,Virginia, USA

Chisholm, I., Bloch. G, Fleisch, B. (2008), "Education, Growth, Aid and Development: towards Education for All". Hong Kong: CERC, 116pages, 978-962809399-1

Cochran-Smith, M. (2001b) Editorial: Higher Standards for Prospective Teachers: What's Missing from the Discourse? Journal of Teacher Education, vol. 52, pp. 179-181

Daun, H. (2001). "Educational Restructuring in the Context of Globalization and National Policy". New York: Garland.

Fernando, Salvetti. (2010). "Global Working, Living and Working across the World with Cultural Intelligence". Milan: Franco Angeli. ISBN 978-88-568-27330.

Holsti, (1969). "Content analysis in Educational Research", M.A, Thesis. Allama lqbal Open University (page 14)

Inkeles.A,Smith,D.H.(1974)."Becoming Modern: Individual Change in Six Developing Countries". Cambridge, MA: Harvard University Press.

Maria,T.T.(2009)."Reforming Teaching and Learning: Comparative Perspectives in a Global Era". Sense Publishers, ISBN 978-94-6091-032-6

Paul.J., Peter, Mandaville.(2010). "Globalization and Culture", Vol. 2: Globalizing Religions. Sage Publications.

Rutledge, (2000). "On Transformations: Reflections on the Work of, and Working with, Gunther Kress." Pp. 16-32, London: Routledge. 